\title{
Education to Liberate Woman of Bajarese Tribe from "Kawin Anom" Culture in South Kalimantan
}

\author{
Norma Yuni Kartika \\ Doctor Candidate in Faculty of Population Study \\ Gadjah Mada University \\ Yogyakarta, Indonesia \\ norma.yuni.k@mail.ugm.ac.id
}

\author{
Muhajir Darwin \\ Faculty of Social and Politics \\ Gadjah Mada University \\ Yogyakarta, Indonesia \\ Sukamdi \\ Faculty of Geography \\ Gadjah Mada University \\ Yogyakarta, Indonesia
}

\begin{abstract}
Education is an important point to achieve Sustainable Development Goals (SDGs) since education is a human right. Education has positive effect to all human aspects. One of the positive effects is through education which has positive relationship with the age of first marriage especially for woman. The objective of this paper is to learn about role of education for woman in order to liberate woman of Banjarese tribe from Kawin Anom culture or early marriage. In this paper, the researcher used primer data analysis from sensus data her in dissertation research. The respondents of the research were women who have marriage for the first time at the age of 16-30 and have been living for about 5 years in the research area. They are those who both have legal marriage according to religious rule and goverment's rule applied in Indonesia. The variables are women having marriage at the age of 16-30 and education. From the results of the paper, education is found to be able to liberate woman from Kawin Anom culture which is still strong in the research area because of the reason that the women are still having their education or they want to study for higher education. These reasons help the women reach their right of education, as one of women's rights which has been neglected due to Kawin Anom or early marriage culture.
\end{abstract}

Keywords - Education, Woman, Kawin Anom Culture, Banjarese Tribe

\section{INTRODUCTION}

One of the points in Sustainable Development Goals (SDGs) is education. Education is a human right without exception. There are many theories and research about education. In this paper, the researcher attempted to learn education variable from civilization related to marriage. There are many studies which conclude education as the key of woman's or man's success, but it affects woman more than man in order not to have early marriage. According to Jensen and Thornton (2003), the increase of woman education contributes to the delay of marriage for woman [1].

According to Jones (1987), marriage culture in Asia is influenced by the background of their local behavior. It seems that this culture is still happening in some regions in South Kalimantan. One of them is in Raya Belanti, Binuang, Tapin. In this region, the characteristic of local behavior related to marriage is Kawin Anom culture which means early marriage. In this area, where most of the villagers are dominated by Banjarese tribe and all of the villagers are Moslems, the practice of Kawin Anom culture is still strong. KUA's (Indonesian term for Religious Affairs Office) data show that this area has the highest practice of the early marriage [2].

In this paper, Kawin Anom means that women have their first marriage when they are below 16 years old. The women who become the respondents are those who have their first marriage at the age of 16-30. This paper discusses the role of education for woman to help Banjarese woman avoid Kawin Anom culture or early marriage.

The definition of education based on the Act No 20/2003 about National Education System is a learning process to enable students to be active to increase their potention, their personality, their knowledge, their behavior and their skill needed for themselves, the society and the country.

According to singh and Samara (1996), in most of developing countries, formal education has increased for the last 30 years. Despite commitment from the government and the family with universal educational concept, national education opportunities for children are different in each region [3]. Savitridina (Marshan, 2011) asserts that women education, their job before they got married, their husband's education, and their lives are the predictors of early marriage, and education is the strongest predictor [5].

\section{METHOD}

In conducting the research, primer data analysis from sensus data in the researcher's dissertation research was used. The women as the respondents are those who got married for the first time when they were 16-30 years old and have been living for about 5 years in the research area. The respondents have legal marriage both according to Islamic rule and 
governmental rule in Indonesia. The variables are women (Banjarese women who have their first marriage at the age of 16-30) and education (education which has finished by the respondents) [6].

\section{RESUlT AND DisCUSSION}

The early marriage in South Kalimantan from 2009 to 2013 based on the data of people prosperity statistics is at the first rank based on the percentage of women at the age of 10 and their first marriage under the age of 16. Nasution (2016) states that the high early marriage percentage in South Kalimantan is due to Kawin Anom culture. The percentage of women who perform "Kawin Anom" culture in Banjarese tribe based on their educational background can be seen in Table 1 [7].

TABle 1. The Percentage Of Banjarese Women Who Do "KaWin ANOM" CULTURE BASED ON EDUCATIONAL BACKGROUND

\begin{tabular}{|l|r|}
\hline \multicolumn{1}{|c|}{ Education } & $\begin{array}{c}\text { Percentage } \\
(\%)\end{array}$ \\
\hline Unfinished Elementary School & 11 \\
\hline Elementary School & 30.8 \\
\hline Junior High School & 37.3 \\
\hline Senior High School & 17.6 \\
\hline DI/DII/DIII & 1.1 \\
\hline DIV/S1 & 2.2 \\
\hline Total & 100 \\
\hline Resource: The result of primary data & \\
\hline
\end{tabular}

Based on Table 1, the highest percentage of women who perform kawin anom culture based on their educational background is at the respondents who finish their junior high school, namely $37.3 \%$. According to the theory of Sakamdi et al. (1995), to increase the age of first marriage, education is needed by pushing the villagers to take a part in education at least till they graduate from junior high school. Based on indent interview, women get married 1-2 years after they have finished their study at junior high school at the age of approximately $15-16[8]$.

Second, there are more respondents who have early marriage with educational background from the category of unfinished elementary school to junior high school (the nineyear compulsory education) $(79.1 \%)$ than those who have finished their education until DI/DII/DIII/DIV/S1 (20.9\%). It means that compulsory education has positive effect although there are still women who do not finish their elementary school or junior high school in the research area. This is in line with Malhotra's research (1997) that the importance of their experience at school is relevant with life transition, such as marriage [9].

Third, the respondents having their marriage after they have finished their senior high school study are $17.6 \%$, those having their marriage after they graduated from DI/DII/DIII are $1.1 \%$ and those having their marriage after graduating from DIV/SI are 2.2\%. According to Dixon (1971), the increase of the opportunity to go to school causes the delay of marriage since there is increasing number of villagers who need to get higher education. The graph showing the percentage of women who can avoid Kawin Anom culture based on their educational background is presented in Figure 1.

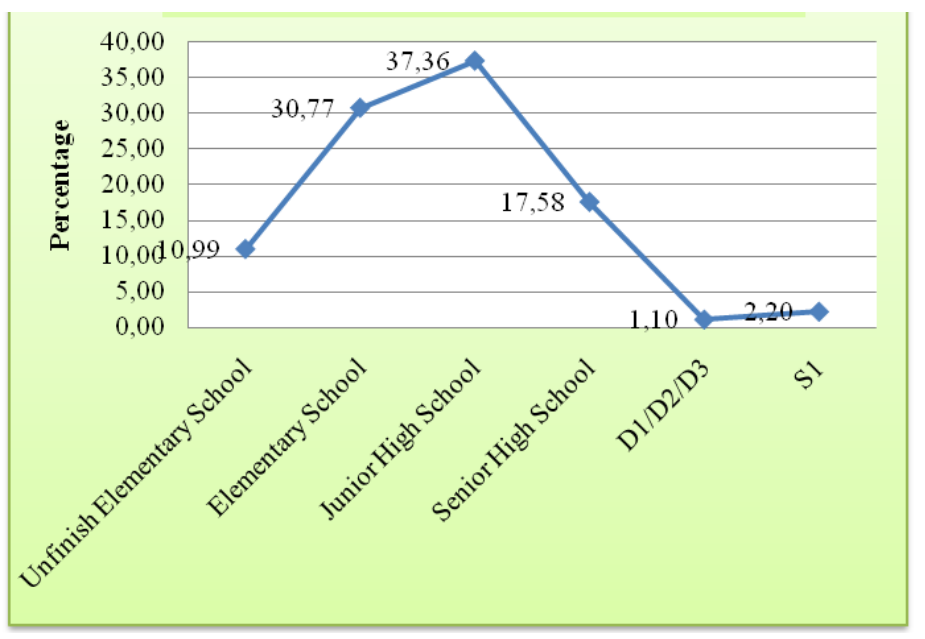

Fig 1. The Percentage Of Women Who Do Kawin Anom Culture Based On Their Educational Background Source: result of primary data

Overall, the percentage of women who have early marriage increases from the category of respondents who have not finished elementary school at $11 \%$ to the category of respondents who have graduated from elementary and junior high schools. The percentage decreased till the level where they finished DIV/SI. This results confirm the research results by Choe et-al (2001) that the higher someone's education is, the lower their marriage level is [10].

It is suggested that women go to school, get higher education and they finish their education since education has positive effect especially for their first age marriage. Indonesian government with their nine-year compulsory education can be reconsidered for revision by applying twelve-year compulsory education, from the six-year elementary school to senior high school. Nowadays there are many policies for poor people to give them motivation and solution. Afterall, the villagers in South Kalimantan especially the women should increase their awareness that they are adult when they are 21 years old. This is based on point 6 part 2 in the Act No 1/1974 about Marriage which state that someone is allowed to do something independently without their parents' permission when they are 21 years old because they are regarded as adults who are able to take responsibility of their own.

\section{CONCLUSION}

Kawin Anom culture in Banjarese tribe especially for women in this area is still strong. It might be related to the occupational background of the people, in which the majority of the villagers' job is farmer, so their awareness of education is low. Moreover, many females did not want to go to school 
because their friends did not either. Consequently, it causes their culture marriage, that is Kawin Anom. From the results of the research in this paper, one of factors which can help the women liberate themselves from Kawin Anom culture is education. Education can help the women avoid early marriage since they are still in school or they want to study at higher education level. If the women continue their study and do not perform early marriage, they will be able to fulfill their right of having education which has been neglected because of Kawin Anom culture or early marriage.

\section{ACKNOWLEDGMENT}

This paper is a part of dissertation done by Norma Yuni Kartika. Gratitude is the dedicated to all dissertation consultants. They are Prof. Dr. Muhajir Darwin as the promoter, the lecturer at Politics and Social Science Faculty in Gadjah Mada University and Dr. Sukamdi, M.Sc. as copromotor and a lecturer of Geography Faculty in Gadjah Mada University.

\section{REFERENCES}

[1] R. Jensen, dan R. Thornton, "Early Female Marriage in The Developing World", Gender and Development, Vol. 11, No. 2 Marriage (Jul, 2003), 2003, pp. 9-19.
[2] G.W. Jones, "Faktor sosial budaya dalam kaitanya dengan Pola Perkawinan di beberapa negara Asean", Bandung: Padjadjaran University, 1987.

[3] S. Singh, and R. Samara, Early Marriage Among Woman In Developing Countries, International Family Planning Perspectives, 22, 1996, pp 148-157 and 175.

[4] O.E. Rafidah, and B. Wahyuni, "Faktor-Faktor Yang Berhubungan Dengan Pernikahan Usia Dini di Kabupaten Purworejo Jawa Tengah, Berita Kedokteran Masyarakat," Vol. 25, No. 2, June 2009, pp. 51-58

[5] J. N. Marshan, M. F. Rakhmadi \& M. Rizky, Prevalence of Chil Marriage and Its Determinants among Young Women in Indonesia, The SMERU Research Institute, UNICEF-Bappenas-SMERU, 2011.

[6] Badan Pusat Statistik, Badan Kependudukan dan Keluarga Berencana Nasional dan Kementerian Kesehatan, Survei Demografi dan Kesehatan Indonesia 2012, Indonesia : BPS, 2013.

[7] Nasution, Ketertindasan Perempuan dalam Tradisi Kawin Anom "Subaltern Perempuan pada Suku banjar dalam Perspekstif Poskolonial”, Yayasan Pustaka Obor Indonesia, 2016.

[8] Sukamdi, "Tingkat, Pola dan Determinan Usia Kawin Wanita dan Pria”, Journal Populasi Vol. 6 No. 2, 1995, pp. 55-77.

[9] A. Malhotra, " Gender and The Minning of Marriage : Rural-Urban Differences in Java", Journal Marriage and Family. Vol 59, No 2, 1991, pp 434-450.

[10] M. K. Choe, S. Thapa and S. I. Achmad, Early Marriage and Chidbearing in Indonesia and Nepal, East-West Center Working Papers, Population, 2001.

[11] Badan Pusat Statistik, Statistik Kesejahteraan Rakyat Kalimantan Selatan tahun 2011, Banjarmasin : BPS Series, No.108-15, 2011.

[12] UNICEF, Early Marriage A Harmful Traditional Practice. The United Nations Children's Fund (UNICEF), 2005. 